\title{
Analisis Curah Hujan di Indonesia untuk Memetakan Daerah Potensi Banjir dan Tanah Longsor dengan Metode Cluster Fuzzy C-Means dan Singular Value Decompotition (SVD)
}

\author{
Dedi Setiawan \\ Binus Graduate Program, Master of Information Technology, \\ Bina Nusantara University, \\ Jakarta, Indonesia 11480 \\ dedi.setiawan001@binus.ac.id
}

Correspondence: dedi.setiawan001@binus.ac.id

\begin{abstract}
One of the climate changes impact is extreme rainfall. Extreme rainfall can cause some hydrometeorological disasters, especially floods and landslides. In 2016, BNPB recorded that there were 2,342 disaster events in Indonesia, 92\% of which were disasters dominated by floods, landslides, and cyclones. There were 766 floods, 612 landslides, and 74 combinations of both. In this case, clustering is one of the important method to identify groups of areas with similar characteristics of high or low rainfall. Another analysis that can be applied is the identification of the extreme rainfall and the determination of dominant rainfall pattern using Singular Value Decomposition (SVD) for each region in Indonesia. The data was taken from Indonesia's rainfall data in January 1998 - March 2017, obtained from the Tropical Rainfall Measuring Mission (TRMM) meteorological satellite, with 12,834 observation units. The highest average rainfall in Indonesia in December is 290,26 mm/month. Rainy season is predicted from November to April because they have the highest average rainfall. The SVD analysis formed four dominant rainfall patterns in Indonesia with a variance of $25.59 \%$, where Papua and West Papua are the regions with the highest rainfall. The area around the Indian Ocean is the area with the most extreme rainfall events compared to other regions. Using Fuzzy C-means, three clusters can be formed, with criteria for areas of high, medium, and low rainfall. Based on the results of the analysis, the area has the potential for flooding and landslides due to high rainfall, so that preventive and mitigation efforts against the risk of flooding and landslides can be treated better.
\end{abstract}

Keywords: Flood; Rainfall; Fuzzy C-Means; SVD; Landslide

Abstrak - Dampak perubahan iklim salah satunya adalah curah hujan extreme. Curah hujan tinggi atau extreme dapat menyebabkan bencana hidrometeorologi, terutama banjir dan tanah longsor. Selama tahun 2016 BNPB mencatat terdapat 2.342 kejadian bencana di Indonesia, 92\% adalah bencana yang didominasi oleh banjir, longsor dan puting beliung. Tercatat 766 bencana banjir, 612 longsor, dan 74 kombinasi keduanya. Clustering menjadi hal yang penting dalam kasus ini, untuk mengetahui kelompok wilayah dengan kemiripan karakteristik curah hujan tinggi/rendah. Analisis lain yang digunakan adalah identifikasi curah hujan extreme dan penentuan pola curah hujan dominan menggunakan Singular Value Decompotition (SVD) setiap wilayah di Indonesia, untuk mengidentifikasi daerah rawan terjadinya banjir dan tanah longsor. Data yang digunakan adalah data curah hujan Indonesia pada Januari 1998 Maret 2017, diperoleh dari satelit meteorologi Tropical Rainfall Measuring Mission (TRMM), dengan unit observasi sebanyak 12.834 lokasi. Rata-rata curah hujan tertinggi di Indonesia pada bulan Desember sebesar 290,26 $\mathrm{mm} /$ month. Bulan Nopember hingga April merupakan bulan yang diprediksi sebagai musim penghujan karena memiliki rata-rata curah hujan tertinggi. Analisis SVD menghasilkan empat pola curah hujan dominan di Indonesia dengan variansi sebesar 25,59\%, dimana Papua dan Papua Barat merupakan wilayah dengan curah hujan tertinggi. Wilayah disekitar Samudera Hindia merupakan wilayah dengan kejadian curah hujan extreme terbanyak dibandingkan dengan wilayah lainnya. Menggunakan Fuzzy C-means dapat dibentuk tiga cluster, dengan kriteria daerah curah hujan tinggi, sedang, dan rendah. Berdasarkan hasil analisis, dapat diketahui daerah berpotensi terjadi bencana banjir dan longsor akibat curah hujan tinggi, sehingga upaya preventif maupun mitigasi terhadap risiko banjir dan longsor dapat dilakukan lebih baik.

Kata Kunci: Banjir; Curah Hujan; Fuzzy C-Means; SVD; Tanah Longsor 


\section{PENDAHULUAN}

Cuaca merupakan salah satu aspek yang menentukan kondisi iklim. Dimana, salah satu faktor yang berpengaruh langsung terhadap perbedaaan tipe atau variasi iklim adalah curah hujan. Curah hujan dengan intensitas tinggi semakin sering terjadi di banyak wilayah di Indonesia. Curah hujan yang tinggi dapat menyebabkan berbagai bencana hidrometeorologi, terutama banjir dan tanah longsor. Selama tahun 2016, berdasarkan data rekapitulasi kejadian dan dampak bencana BNPB, terdapat 2.342 kejadian bencana di Indonesia. Dimana 92\% dari jumlah tersebut adalah bencana hidrometeorologi yang didominasi oleh banjir, longsor dan puting beliung. Tercatat bahwa pada tahun ini terdapat 766 bencana banjir, 612 longsor, dan 74 kombinasi banjir dan longsor. Dimana penyebab utama banjir dan tanah longsor tersebut tidak lain adalah tingginya curah hujan pada wilayah tersebut. Dampak yang ditimbulkan oleh bencana-bencana ini tidak dapat diremehkan, baik nyawa, kesehatan, kerusakan rumah dan fasilitas umum yang tercatat sebanyak 522 orang meninggal dunia dan hilang, 3,05 juta jiwa mengungsi dan menderita, 69.287 unit rumah rusak, dan 2.311 unit fasilitas umum rusak. Beragam data curah hujan di Indonesia mulai tahun 1998 bulan januari sampai 2017 bulan maret dapat diperoleh dari satelit-satelit meteorologi TRRM (Tropical Rainfall Measuring Mission) dengan sensornya PR (Precipitation Radar), TMI (TRMM Microwave Imager), VIRS (Visible and Infrared Scanner). Data tersebut menunjukkan catatan curah hujan di berbagai wilayah di Indonesia dengan format hdf.

Mengingat kerugian yang harus ditampung sangat besar akibat dari ketiadaan antisipasi curah hujan yang tinggi, hingga dapat menimbulkan bencana bagi daerah tertentu, maka usaha untuk mengetahui pola-pola dan karakterisik khusus dari curah hujan merupakan hal penting untuk dilakukan. Selain itu upaya mengetahui clustercluster curah hujan sesuai dengan karakteristiknya juga penting dilakukan agar upaya-upaya preventif maupun mitigasi terhadap risiko bencana yang dapat terjadi karena curah hujan dapat dilakukan lebih baik.

Andi Ihwan melakukan pemodelan curah hujan di Kota Pontianak dengan metode Least Square non Linear (Andi, 2010). Penelitian tersebut menggunakan metode yang kurang tepat karena data curah hujan merupakan data spasial yang mengandung unsur waktu, sehingga memerlukan perlakuan khusus dan tidak dapat diolah langsung menggunakan metode Least Square. Made Dwi dkk menggunakan metode Singular Vector Decomposition untuk mengetahui pola bulanan curah hujan di Sulawesi Selatan dengan angin monsoon Asia dan Australia (Dwi et al., 2014). Sementara Novianti dkk menganalisis curah hujan dengan melakukan clustering curah hujan di Kalimantan Timur menggunakan metode K-means (Novianti et al., 2016). Penelitian made hanya berfokus pada pola curah hujan dan penelitian Novianti hanya berfokus pada clustering curah hujan. Kedua penelitian tersebut akan menghasilkan analisis yang lebih informatif jika masingmasing penelitian menggabungkan kedua fokus tersebut.
Tujuan dari penelitian ini adalah mengetahui polapola dominan dari curah hujan di setiap wilayah di Indonesia serta mengetahui cluster-cluster daerah tingkat curah hujan sesuai dengan karakteristiknya. Manfaat yang diharapkan dalam penelitian ini adalah didapatkannya kelompok daerah-daerah di wilayah Indonesia yang memiliki tingkat curah hujan tinggi, sedang dan rendah sehingga dapat menjadi salah satu saran dilakukannya upaya preventif terhadap terjadinya bencana banjir dan tanah longsor, serta dapat menjadi pertimbangan bagi berbagai aktivitas masyarakat yang erat keterkaitannya dengan curah hujan. Sedangkan, pada penelitian ini, metode clustering yang digunakan adalah Fuzzy C-means clustering, sedangkan Singular Value Decomposition untuk menganalisis pola dominan dari tingkat curah hujan di wilayah Indonesia.

\section{METODOLOGI PENELITIAN}

Pada analisis ini, metode yang digunakan meliputi metode untuk preprocessing data dan metode analisis data. Metode preprocessing data yang digunakan adalah Feature creation. Sedangkan untuk metode analisis yang digunakan adalah clustering menggunakan Fuzzy C-Means dan juga metode identifikasi pola curah hujan dominan menggunakan Singular Value Decompotition.

\subsection{Tahap Pre-Processing}

Tahap ini merupakan tahap untuk mempersiapkan data sebelum diolah menggunakan data mining dengan metode apapun. Secara umum, ada beberapa cara yang dapat digunakan pada tahap pre-processing ini (Florin, 2011), yaitu :

- Aggregation, yaitu mengombinasikan dua objek atau lebih guna mereduksi jumlah objek yang ingin diolah, dalam hal ini bisa observasi ataupun variabel.

- Sampling, yaitu pemilihan sebagian dari keseluruhan data yang akan digunakan. Langkah ini hampir sama dengan langkah sebelumnya, yaitu bertujuan untuk mengurangi jumlah data, namun dengan tidak menghilangkan karakteristik populasi.

- Dimensionality reduction, yaitu mereduksi dimensi, baik variabel maupun observasi demi memperkecil volume memori dan mempersingkat waktu pemrosesan. Biasanya digunakan factor analysis, principal components analysis, multidimensional scaling, cluster analysis, canonical correlation, dan lain sebagainya.

- Feature selection digunakan untuk menghilangkan fitur-fitur atau variabel yang kurang relevan dan yang dapat menimbulkan kebingungan.

- Feature creation, yaitu membuat artificial attribute sehingga dapat menangkap informasi penting dari data daripada hanya menggunakan attribute yang asli. 
- Discretization and binarization, yaitu transformasi data dari kontinyu ke diskret atau dari banyak nilai ke biner.

- Attribute transformation, konversi yang dilakukan kepada attribute lama ke attribute baru menggunakan transformasi matematis tertentu sehingga dapat dilakukan pemrosesan data dengan lebih baik.

\subsection{Tahap Analisis}

Pada penelitian ini metode yang digunakan adalah Fuzzy C-Means Clustering (FCM) dan Singular Value Decompotition (SVD). Berikut merupakan penjelasan dari metode yang digunakan.

\subsubsection{Statistika Deskriptif}

Statistika deskriptif adalah metode-metode yang berkaitan dengan pengumpulan dan penyajian suatu gugus data sehingga memberikan informasi yang berguna. Mean adalah salah satu ukuran untuk memberikan gambaran yang lebih jelas dan singkat tentang sekumpulan data. Mean juga merupakan wakil dari sekumpulan data atau dianggap suatu nilai yang paling dekat dengan hasil pengukuran yang sebenarnya. Rumus yang digunakan untuk menghitung mean data adalah :

$$
\bar{x}=\frac{1}{n} \sum_{i=1}^{n} x_{i}
$$

keterangan,

$x_{i} \quad=$ data pengamatan ke-i

$n \quad$ = banyaknya data

Standar deviasi merupakan akar kuadrat dari varians. Rumus yang digunakan untuk menghitung nilai standar deviasi adalah :

$$
s=\sqrt{\frac{\sum_{i=1}^{n}\left(x_{i}-\bar{x}\right)^{2}}{n-1}}
$$

keterangan,

$s \quad=$ standar deviasi

$x_{i} \quad=$ nilai tengah

$x \quad=$ rata-rata

$n \quad=$ banyak data

Nilai minimum adalah nilai terendah dari suatu data. Sedangkan nilai maksimum adalah nilai tertinggi dari suatu data (Hair, 1995).

\subsubsection{Fuzzy C-Means Clustering (FCM)}

Fuzzy C-Means (FCM), atau dikenal juga sebagai Fuzzy ISODATA, merupakan salah satu metode mapping maupun clustering yang merupakan bagian dari metode Hard K-Means. FCM menggunakan model pengelompokan fuzzy sehingga data dapat menjadi anggota dari semua kelas atau cluster terbentuk dengan derajat atau tingkat keanggotaan yang berbeda antara 0 hingga 1 .

Tingkat keberadaan data dalam suatu kelas atau cluster ditentukan oleh derajat keanggotaannya. Teknik ini pertama kali diperkenalkan oleh Jim Bezdek pada tahun 1981. Konsep dasar FCM, pertama kali adalah menentukan pusat cluster yang akan menandai lokasi ratarata untuk tiaptiap cluster (Kusumadewi, 2013). Pada kondisi awal, pusat cluster ini masih belum akurat. Tiap-tiap data memiliki derajat keanggotaan untuk tiap-tiap cluster. Dengan cara memperbaiki pusat cluster dan nilai keanggotaan tiap-tiap datasecara berulang, maka dapat dilihat bahwa pusat cluster akan menujui lokasi yang tepat. Perulangan ini didasarkan pada minimasi fungsi obyektif (Velmurugan \& Santhanan, 2010).

Dalam metode fuzzy c-means dipergunakan variabel membership function (uik), yang merujuk pada seberapa besar kemungkinan suatu data bisa menjadi anggota ke dalam suatu kelompok. Centroid dari masing-masing kelompok dapat dihitung dengan menggunakan rumus sebagai berikut,

$$
v_{k j}=\frac{\sum_{i=1}^{n}\left(u_{i k}\right)^{w_{x_{i j}}}}{\sum_{i=1}^{n}\left(u_{i k}\right)^{w}} v_{k j}=\frac{\sum_{i=1}^{n}\left(u_{i k}\right)^{w_{x_{i j}}}}{\sum_{i=1}^{n}\left(u_{i k}\right)^{w}}
$$

dimana :

$n \quad$ = Banyaknya data

$i \quad=$ Indeks objek ke- $i$

$k \quad=$ Indeks cluster ke- $k$

$u_{i k} \quad=$ Keanggotaan data objek ke- $i$ dan cluster ke- $k$

$v_{k j}=$ Centroid/rata rata cluster ke- $k$ untuk variabel ke-j

$w=$ Weighting exponent

$x_{i j}=$ Nilai objek ke- $i$ yang ada didalam cluster tersebut untuk variabel ke- $j$

\subsubsection{Singular Value Decomposition (SVD)}

Metode SVD adalah metode yang menguraikan matriks $A$ menjadi tiga komponen $U S V^{H,}$ dimana $U$ adalah matriks dengan ukuran $m \times m, S$ adalah matriks dengan ukuran $m \times n$ yang entrinya di luar diagonal $O$, dan $V$ adalah matriks dengan ukuran $n \times n$. Proses dekomposisi ini sering disebut dengan faktorisasi. Berikut ini akan diberikan definisi dari nilai singular.

Definisi 1: Diketahui $A \in \mathbb{C}^{m \times n} A \in \mathbb{C}^{m \times n}$ matriks dengan $\operatorname{rank}(A)=r(A)=r$, dimana $r \leq \min (m, n)$ $r \leq \min (m, n)$. Eigenvalue dari matrik $A^{H} A A^{H} A$ adalah:

$\lambda_{1} \geq \lambda_{2} \geq \cdots \geq \lambda_{r}>\lambda_{r+1}=\cdots=\lambda_{n}=0$

Nilai akar positif dari eigen $A^{H} A A^{H} A$ disebut sebagai nilai singular $(\sigma)(\sigma)$ matriks $A$ dan $d$ (Howard, 2000).

\subsection{Dataset}

Data yang digunakan adalah data curah hujan di Indonesia untuk setiap titik yang diperoleh dari Badan Meteorologi, Klimatologi dan Geofisika. Data terdiri atas 12834 titik/lokasi. Data dari TRRM (Tropical Rainfall Measuring Mission) hanya memiliki 1 atribut saja yaitu curah hujan dalam satuan $\mathrm{mm} /$ month. Data curah hujan yang digunakan mulai bulan Januari 1998 sampai Maret 2017. Dari atribut curah hujan dinilai masih belum cukup menggambarkan keadaan tiap-tiap wilayah di Indoneisa, maka dilakukan feature creation dengan cara membuat atribut baru yang berisikan nilai-nilai maksimum, rata-rata dan standar deviasi dari atribut curah hujan. 


\section{HASIL DAN PEMBAHASAN}

\subsection{Karakteristik Curah Hujan di Indonesia}

Karakteristik curah hujan di Indonesia dapat dilihat menggunakan statistika deskriptif rata-rata, rata-rata yang dihitung berdasarkan perbulan sehingga diketahui keadaan curah hujan untuk setiap bulannya. Selain itu juga dapat diketahui kecenderungan curah hujan setiap bulan dan mengetahui bulan dengan rata-rata curah hujan terendah maupun tertinggi. Berdasarkan Gambar 1 dibawah ini dapat diketahui bahwa curah hujan tertinggi dan merupakan puncak musim hujan terjadi pada bulan Desember yaitu dengan rata-rata curah hujan sebesar $290,26 \mathrm{~mm} /$ month sedangkan puncak musim kemarau terjadi pada bulan Agustus dengan curah hujan rata-rata hanya sebesar 150,61 $\mathrm{mm} / \mathrm{month}$. Seperti yang diketahui bahwa secara teori musim hujan terjadi pada bulan Oktober hingga Maret. Pada Gambar 1 merupakan rata-rata curah hujan bulanan di Indonesia untuk tahun 1998 hingga 2017.

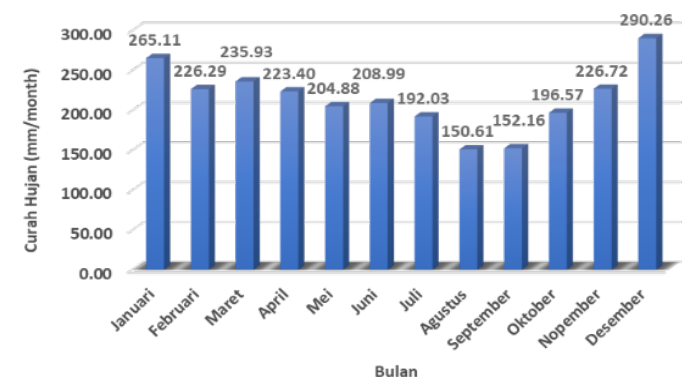

Gambar 1. Rata-rata Curah Hujan di Indonesia Tahun 1998-2017

Pada Gambar 1 dapat menjelaskan bahwa bulan Nopember hingga April merupakan bulan dengan curah hujan diatas rata-rata sehingga pada bulan tersebut di Indonesia diprediksi sebagai musim penghujan. Sedangkan bulan Mei hingga Oktober memberikan hasil sebaliknya dimana pada bulan tersebut memiliki curah hujan yang cenderung rendah, sehingga diprediksi sebagai musim kemarau di Indonesia. Setiap bulan curah hujan di Indonesia memiliki pola naik pada bulan Agustus hingga bulan Desember, namun pada bulan Desember hingga Agustus rata-rata curah hujan bulanan di Indonesia cenderung turun. Terdapat dua puncak maksimum dan minum yaitu maksimum untuk bulan Desember dan minimum untuk bulan Agustus. Berdasarkan rata-rata curah hujan setiap wilayah di Indonesia untuk setiap bulannya (Lampiran 1) dapat diketahui bahwa musim kemarau di Indonesia seolaholah berangkat dan berakhir dari samudera Hindia. Sehingga Indonesia bagian selatan meliputi sebagaian Jawa, Bali dan Nusa Tenggara cenderung memiliki musim kemarau yang lebih lama. Sedangkan untuk wilayah di Sebagian Sumatera, Kalimantan dan Papua merupakan wilayah dengan curah hujan tinggi yang lebih lama.

Selanjutnya diperlihatkan rata-rata curah hujan di setiap wilayah di Indonesia mulai bulan Januari 1998 hingga bulan Maret 2017 pada Gambar 2 seperti dibawah ini.

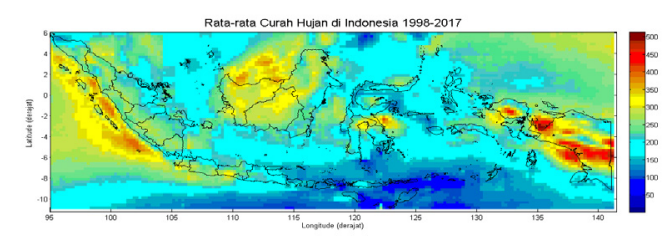

Gambar 2. Rata-rata Curah Hujan Setiap Lokasi di Indonesia Tahun 1998-2017

Berdasarkan Gambar 2 diatas, dapat diketahui bahwa wilayah yang mempunyai curah hujan tinggi adalah daerah Papua dan Papua Barat dimana pada wilayah tersebut memiliki curah hujan rata-rata bulanan berkisar diantara 300-550 mm/month. Sedangkan untuk wilayah Bali, NTT dan NTB mempunyai rata-rata curah hujan yang rendah hal ini mengindikasikan bahwa untuk wilayah tersebut mempunyai intensitas kemarau yang lebih sering. Wilayah Kalimantan, Sulawesi dan Sumatera masih memiliki curah hujan yang normal yaitu berkisar di angka $250 \mathrm{~mm} /$ month.

\subsection{Identifikasi Curah Hujan Esktrim}

Pada sub bab ini akan dijelaskan mengenai curah hujan ekstrim untuk setiap wilayah di Indonesia, dimana metode yang digunakan adalah distribusi kumulatif dengan menggunakan alfa $(\alpha)$ sebesar 0,005. Meng-gunakan metode distribusi kumulatif tersebut maka didapatkan nilai ambang batas curah hujan ekstrim dapat ditampilkan pada Gambar 3 berikut:
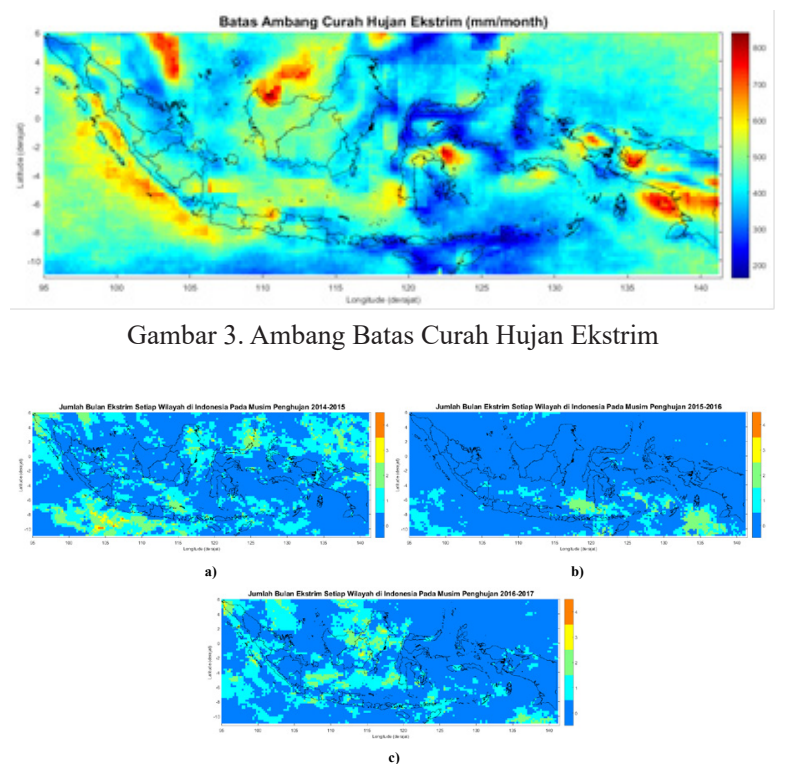

Gambar 4. Peta Jumlah Curah Hujan Ekstrim Setiap Daerah

Berdasarkan Gambar 4 diatas, identifikasi curah hujan ekstrim selama 3 musim penghujan terakhir, setiap tahunnya lokasi terjadinya berubah-ubah hal ini mungkin diakibatkan karena adanya perumahan iklim yang sangat berdampak bagi segala aspek kehidupan. Jika dilihat lokasi terjadinya curah hujan ekstrim kecenderungan berada di wilayah laut, dimana untuk wilayah Samudera Hindia yang sering terjadi. Pada musim hujan periode terakhir, wilayah Kalimantan merupakan wilayah dengan kejadian curah hujan ekstrim lebih sering dengan wilayah lain, hal ini perlu dilakukan antipassi akan dampak keajadian ini terutama risiko bencana banjir, tanah longsor maupun badai. 


\subsection{Pengelompokan Daerah Berdasarkan Curah Hujan}

Pada penelitian ini dilakuakan clustering untuk setiap 0,250 wilayah di Indonesia, sehingga secara keseluruahan akan dilakuakn clustering sebanyak 12.834 wilayah. Clustering dilakukan pada musim penghujan yaitu pada bulan Oktober hingga Maret untuk tahun 2014 hingga tahun 2017 atau selama 3 musim di Indonesia. Dengan menggunakan metode Fuzzy C-means Cluster dilakukan pembentukan kelompok sebanyak 3 cluster, kelompok dibedakan menjadi kelompok dengan daerah curah hujan rendah, sedang, dan tinggi.

Berdasarkan hasil clustering menggunakan algoritma fuzzy c-means dapat diketahui bahwa pola atau hasil pengelompokan untuk 3 musim hujan terakhir hampir sama, dimana untuk wilayah sebagian wilayah Sumatera, Jawa, Kalimantan dan Papua cenderung untuk masuk ke kelompok curah hujan sedang dan tinggi, sedangkan untuk wilayah Bali, Nusa Tenggara dan Maluku masuk ke dalam kelompok dengan rata-rata curah hujan yang rendah.

Selanjutnya perlu dilakukan analisis untuk mengetahui karakteristik setiap cluster pada ketiga musim hujan (2014-2017), berikut grafik perbandingan rata-rata curah hujan setiap kelompok.

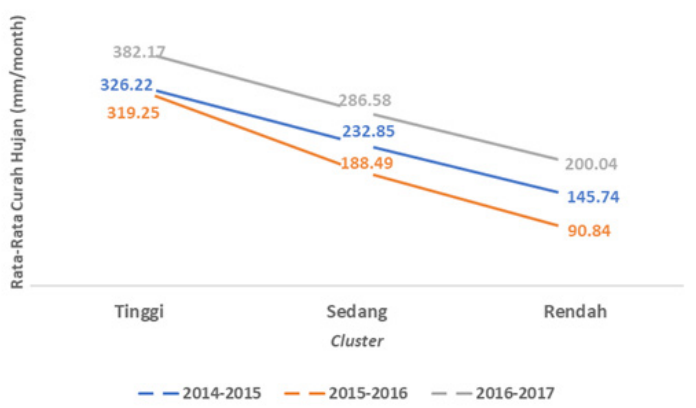

Gambar 5. Grafik Perbandingan Tiap Cluster Berdasarkan Curah Hujan Rata-Rata

Berdasarkan Gambar 5 dapat diketahui bahwa musim hujan tahun 2015-2016 memiliki rata-rata curah hujan yang paling rendah selama 3 tahun terakhir, sedangkan untuk musim hujan periode 2016-2017 memiliki rata-rata yang paling tinggi. Perbedaan rata-rata curah hujan setiap tahunnya sangat bervariasi hal ini terjadi akibat dari perubahan iklim. Berikut merupakan gambar untuk perbandingan jumalah anggota setiap cluster yang terbentuk.

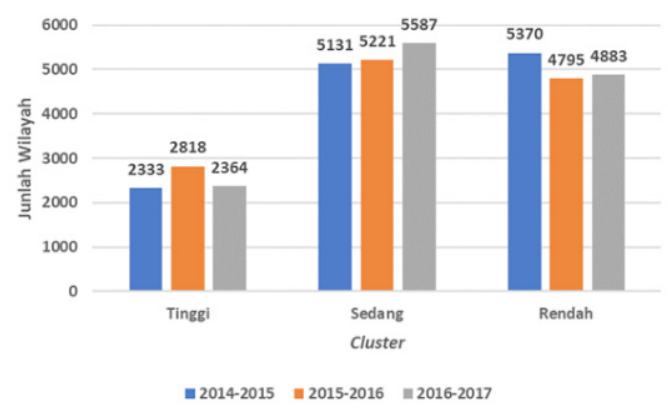

Gambar 6. Perbandingan Setiap Cluster dan Setiap Musim Berdasarkan Jumlah Daerah

Berdasarkan Gambar 6 dapat diketahui bahwa ratarata wilayah di Indonesia masuk kedalam cluster sedang dan rendah. Sedangkan untuk anggota cluster paling sedikit yaitu sebanyak 18\% hingga 22\% dari keseluruhuan wilayah di Indonesia (lokasi pengamatan).

\subsection{Identifikasi Pola Curah Hujan di Indonesia}

Pola curah hujan dominan di Indonesia dapat diketahui dengan metode analisis Singular Value Decompotition (SVD). Analisis SVD dilakukan menggunakan software Matlab R2010a, dimana satuan data yang digunakan adalah $\mathrm{mm} /$ hour. Hasil pola dominan yang terbentuk sebanyak empat pola dengan nilai variansi sebesar 25,59\%. Empat pola dominan untuk curah hujan di Indonesia sebagai berikut.

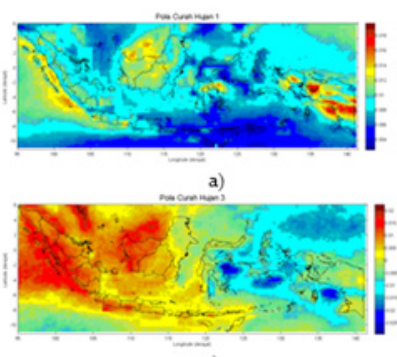

c)

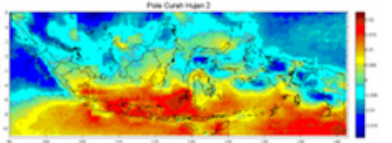

b)

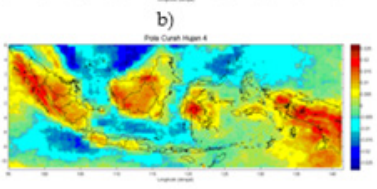

d)
Gambar 7 a-d. Pola Curah Hujan Dominan

Berdasarkan Gambar 7a dapat diketahui bahwa untuk sebagaian wilayah Papua dan Papua Barat memiliki curah hujan yang paling tinggi di bandingkan dengan daerah lain di Indonesia, untuk pola curah hujan ini menghasilkan nilai variansi sebesar 16,69\%. Sedangkan untuk pola curah hujan ke-2 memberikan nilai variansi kumulatif sebesar 20,56\% pada pola ini untuk wilayah Indonesia bagian selatan termasuk pulau Jawa, Nusa Tenggara, Bali, dan Samudera Hindia memiliki curah hujan paling tinggi dibandingkan dengan daerah lain di Indonesia. Pola curah hujan ke-3 dihasilkan bahwa untuk wilayah Indonesia Barat termasuk seluruh wilayah di Sumatera, Jawa, Bali, Nusa Tenggara dan Kalimantan memiliki curah hujan yang sangat rendah bila dibanding dengan wilayah lain dan pola ini memberikan nilai variansi kumulatif sebesar 23,57\%. Untuk pola curah hujan dominan yang ke-4 dapat diketahui untuk seluruh wilayah di Indonesia memiliki curah hujan yang tinggi hal ini juga berakibat pada terjadinya musim hujan di semua wilayah. Total variansi yang dijelaskan oleh empat komponen utama melalui metode SVD sebesar $25,59 \%$.

Menggunakan metode Singular Value Decompotition didapatkan tiga jenis matriks dan vektor dekomposisi yaitu, matriks U, S, dan V. Vektor V merupakan vektor singular yang menunjukkan plot data time series atau pola temporal dari analisis SVD.

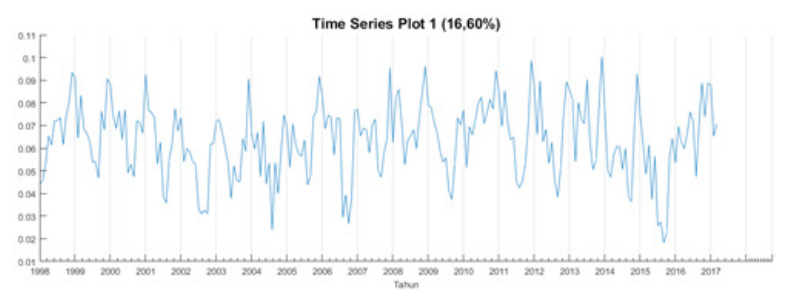

Gambar 8. Plot Deret Waktu atau Vektor Temporal Singular dari Metode SVD 
Grafik temporal yang dihasilkan metode SVD untuk pola 1 pada Gambar 8 memperlihatkan siklus dengan periode tahunan yang dominan berada di setiap titik puncaknya. Hal ini diduga pengaruh fenomena musiman yang terjadi setiap tahunnya. Pada pola ini nilai tahun 2014 terdapat pada titik paling tinggi, artinya pada tahun tersebut curah hujan di Indonesia banyak bervariasi dengan perubahan variannya cukup besar. Pola tahunan juga terjadi untuk pola kedua dan ketiga. Pada Pola keempat dengan memberikan nilai variansi kumulatif sebesar 25,60\% memperlihatkan siklus curah hujan dengan periode bulanan, selain itu juga dapat dilihat bahwa penampakan untuk siklus yang semakin melemah.

\section{KESIMPULAN}

Berdasarkan analisis dan pembahasan pada bab 4 diatas maka dapat ditarik kesimpulan sebagai berikut:

1. Berdasarkan hasil rata-rata curah hujan bulanan, musim penghujan akan dimulai pada bulan Nopember hingga April karena pada bulan ini rata-rata curah hujan di Indonesia sangat tinggi, sedangkan untuk musim kemarau terjadi pada bulan Mei hingga Oktober. Di mana bulan Desember akan terjadi puncak musim hujan dan bulan Agustus puncak musim kemarau. Berdasarkan nilai rata-rata curah hujan wilayah Papua dan Papua Barat merupakan wilayah yang mempunyai curah hujan tertinggi, sedangkan untuk wilayah Bali dan Nusa Tenggara merupakan wilayah dengan curah hujan yang cenderung rendah.

2. Curah hujan ekstrim di Indonesia selama 3 musim hujan terakhir sangat bervariasi, dimana maksimal jumlah curah hujan ekstrim sebanyak 4 bulan. Wilayah disekitar Samudera Hindia merupakan wilayah dengan kejadian curah hujan ekstrim paling sering disbanding wilayah lain di Indonesia. Untuk curah hujan ekstrim satu musim terakhir sebagian wilayah di Kalimantan sering terjadi curah hujan ekstrim rata-rata interval kejadian 1-2 bulan.

3. Menggunakan cluster fuzzy c-means terbentuk tiga cluster yaitu dengan kriteria cluster dengan ratarata curah hujan rendah, sedang, dan tinggi. Wilayah sebagian wilayah Sumatera, Jawa, Kalimantan dan Papua cenderung untuk masuk ke kelompok curah hujan sedang dan tinggi, sedangkan untuk wilayah Bali, Nusa Tenggara dan Maluku masuk ke dalam kelompok dengan rata-rata curah hujan yang rendah. Kecenderungan wilayah di Indonesia masuk kedalam cluster rendah dan sedang, sedangkan untuk cluster tinggi hanya sebesar 18-22\% dari keseluruhan wilayah di Indonesia.

4. Berdasarkan analisis Singular Value Decompotition (SVD) didapatkan terdapat 4 pola curah hujan dominan di Indonesia, dimana dengan keempat pola dominan tersebut didapatkan nilai variansi sebesar 25,60\% saja. Pola dominan curah hujan pertama hingga ketiga mempunyai siklus tahunan, sedangkan untuk pola keempat mempunyai siklus curah hujan bulanan. Hasil yang diperoleh bahwa pulau Papua dan Papua Barat merupakan daerah dengan curah hujan tertinggi.

\section{DAFTAR PUSTAKA}

Anton, Howard (2000). "Elementary Linear Algebra", Eighth Edition. John Wiley, New York.

Dwi, Made.,Wahyu, Tri., \& Syahputra, M Rido. (2014). Bukit Kotabang : MEGASAINS.

Gorunescu, Florin. (2011). Data Mining: Concepts, Models, and Techniques. Berlin : Springer.

Hair, J. F. Jr. (1995). Multivariate Data Analysis with Readings, 4th edition. Madison : Pearson Prentice-Hall.

Ihwan, Andi. (2010). Pemodelan Curah Hujan Bulanan Berdasarkan Metode Least Square non Linear. Pontianak: Prodi Fisika FMIPA Universitas Tanjungpura.

Kusumadewi, S., (2003). Artificial Intellegence (Teknik dan Aplikasinya), Yogyakarta: Graha Ilmu.

Puspitasari, Novianti \& Haviluddin. (2016). Penerapan Metode K-Means dalam Pengelompokan Curah Hujan di Kalimantan Timur. Samarinda : Universitas Mulawarman.

Velmurugan, V. dan Santhanan, T., (2010). Clustering Mix Data Point Using Fuzzy CMeans Clustering Algorithm for Performance Analysis, International Journal on Computer Science and Engineering (IJCSE),Vol.02 , No.09, 2010, 31003105 . 